MH EK Neurológia, Alvásdiagnosztikai és Terápiás Centrum

\title{
Az obstruktív alvási apnoe epidemiológiai szürése célpopulációban
}

\author{
Dr. habil Szakács Zoltán orvos ezredes, PhD
}

Kulcsszavak: alvási apnoe, szív-és érrendszeri betegségek, elhizás

Az obstruktív alvási apnoe (OSA) valószínüleg a leggyakoribb alvásfüggő légzési rendellenesség. Az Egyesült Államok és Európa legfrissebb adatai szerint a középkorú férfiak 14-49\%-a rendelkezik klinikailag jelentős OSA-val. Az OSA és az elhízás közötti szoros kapcsolat azt jelenti, hogy prevalenciája jelentősen fokozódik a globális elhízási járvány kialakulása kapcsán. Egyéni szinten az OSA az életminőség és a funkcionális képesség jelentős csökkenéséhez vezet, a szív- és érrendszeri betegségek és a halál jelentősen megnövekedett kockázata mellett. A felmerülő adatok arra is utalnak, hogy az OSA jelenléte és súlyossága, valamint a kapcsolódó éjszakai hipoxémia, a cukorbetegség és a rák megnövekedett kockázatával jár. Társadalmi szinten az OSA nemcsak a gazdasági termelékenység csökkenéséhez vezet, hanem a magas vérnyomás, a koszorúér-betegség és a stroke egyik fő kezelhető kockázati tényezője. Ez a cikk epidemiológiai szempontból foglalkozik hazánkban az OSA prevalenciájával és az egyuittes morbiditással.

Az obstruktív alvási apnoe szindróma (OSAS) az excesszív mértékủ nappali aluszékonyság leggyakoribb oka [1,2]. A keresztmetszeti vizsgálatokban az OSAS minimális előfordulása a felnőtt férfiak körében körülbelül $1 \%[3,4]$. A prevalencia a 40-65 éves férfiaknál a legmagasabb [5]. E korcsoportban a klinikailag szignifikáns OSAS előfordulása 8,5\% [6]. A habituális horkolás az OSAS leggyakoribb tünete (70-95\%) [7]. Az OSAS legfontosabb kockázati tényezője az elhízás. A horkolás és az OSAS egyéb kockázati tényezői a férfi nem, a 40 és 65 év közötti életkor, a cigarettázás, az alkoholfogyasztás és a rossz fizikai erőnlét. A horkolás és az obstruktív alvási apnoe szintén nagyon gyakori az akromegáliában szenvedő férfiaknál [8].

Sok más olyan szindróma, vagy betegség létezik, amelyekben a felső légút szűkül. A horkolás és az alvási apnoe 
előfordulása minden ilyen helyzetben fokozódik. Felmerült, hogy az alvási apnoe lehet az alvással összefüggő halálozás egyik mechanizmusa. Úgy tünik, hogy a rendszeres horkolás előfordulása 65 éves kor után nő. A 65 év feletti személyek több, mint $25 \%$-a óránként több, mint öt apnoet szenved el az alvása során [9].

Az alvási apnoe a kardio- és cerebrovaszkuláris rizikó egyik meghatározó tényezője $[10,11]$. Az esszenciális hipertóniában szenvedő betegek körében az alvási apnoe prevalenciája meghaladja a $25 \%$-ot [12]. Ezért a hipertóniában szenvedő betegeket mindig ki kell kérdezni a horkolásukról és gondolni kell az alvási apnoe lehetőségére.

A kezelés és a diagnózis az elmúlt 25 évben nagyrészt változatlan maradt [13]. Közepes, vagy súlyos obstruktív alvási apnoe szindróma esetén a folyamatos pozitív légúti nyomással történő kezelés bizonyult hatékonynak [14]. Kérdéses továbbra is, hogy hogyan lehet szürni az alvásfüggő légzészavarban szenvedő betegeket. Szükséges-e időigényes, nagy érzékenységü és specifitású diagnosztikai eljárásokat igénybe venni, vagy a veszélyeztetett populációk szürésére egyszerübb módszereket kell alkalmazni pl. az alapellátási szektorban?

\section{Módszerek}

A prevalencia vizsgálatban az OSAS szürését célcsoportban végeztük, 1500 35-65 év közötti férfi és nő körében. A kérdőíves szürővizsgálatra történő beválasztás feltétele az 1. táblázatban szereplő betegség, vagy az OSAS-ra jellemző panaszok egyike volt. A háziorvosok a vizsgálatba vont személyeket az 1. táblázat szempontjai szerint választották ki:
1. táblázat. $A z$ OSAS-szürésébe bevont személyek kiválasztási feltételei

\begin{tabular}{|l|l|}
\hline BETEGSÉGEK & PANASZOK \\
\hline hipertónia & horkolás \\
\hline túlsúly & kóros aluszékonyság \\
\hline sztrók & feledékenység \\
\hline szívinfarktus & $\begin{array}{l}\text { szellemi teljesítmény } \\
\text { hanyatlása }\end{array}$ \\
\hline cukorbetegség & ingerlékenység \\
\hline $\begin{array}{l}\text { krónikus felsőlégúti } \\
\text { betegség }\end{array}$ & $\begin{array}{l}\text { reggeli fejfájás, } \\
\text { tompultság, zavartság }\end{array}$ \\
\hline & hangulati nyomottság \\
\hline & tartós alvásképtelenség \\
\hline
\end{tabular}

A vizsgálatban két $\mathrm{HM}$ rendelő (budapesti és kecskeméti honvédkórház) és tíz családorvosi körzet vett részt. A családorvosi körzetekhez tartozó két szakorvosi rendelőintézet is bekapcsolódott a munkába. A háziorvosok által ellátott betegek összlétszáma 20000 volt. Ebből a célcsoportoké 8000 fö.

\section{Az OSAS-szürésénél alkalmazott kérdöív}

Az alábbi szűrésekben az alváslaboratóriumunkban, a speciálisan erre a célra szerkesztett összetett kérdőívet alkalmaztunk. A kérdőív kitöltése során maximálisan 336 pontot lehetett elérni, amely tartalmazta az Epworth-skálát is. A kérdőív célja az OSAS jellemző tüneteinek részletezése, a szövődmények jelenlétének felfedezése, az életmód és a szokások feltérképezése. A kérdőívek kérdéseiből faktorokat képeztünk, amelyek a jellemző tüneteket, illetve szövődményeket tartalmazzák (2. táblázat).

$\mathrm{Az}$ elérhető pontértékek alapján képeztünk az OSAS-gyanúját alátámasztó kategóriákat, amelyek beosztását a 3. táblázat mutatja. Betegeink összesen 12548 kérdőívet töltöttek ki. 
Ezt követően 6356 esetben kardiorespiratórikus poligráfiás vizsgálatot végeztünk. A betegség súlyosságának objektív meghatározására az apnoehypopnoe indexet használtuk. A kérdőíves szürés és a kardiorespiratórikus vizsgálatok eredményét összegző kontingencia táblázatot a 4. táblázat mutatja.

2. táblázat. $A z$ OSAS kérdőív faktorai

\begin{tabular}{|l|l|}
\hline $\begin{array}{l}\text { JELLEMZÖ } \\
\text { TÜNETEK }\end{array}$ & SZÖVÖDMÉNYEK \\
\hline $\begin{array}{l}\text { I. Napközbeni } \\
\text { aluszékonyság }\end{array}$ & VII. Hipertónia \\
\hline II. Mentális deficit & VIII. Túlsúly \\
\hline III. Alvásfragmentáció & IX. Dohányzás \\
\hline IV. Horkolás & X. Altatószer használat \\
\hline V. Mozgás alvásközben & $\begin{array}{l}\text { XI. Kardiovaszkuláris } \\
\text { szövődmény }\end{array}$ \\
\hline VI. Reggeli panaszok & $\begin{array}{l}\text { XII. Cerebrovaszkuláris } \\
\text { szövődmény }\end{array}$ \\
\hline
\end{tabular}

3. táblázat. A kérdöív által elérhetó pontértékek és az OSAS-gyanú mértéke

\begin{tabular}{|l|c|l|}
\hline KATEGÓRIA & PONTÉRTÉK & $\begin{array}{l}\text { ELÉRHETŐ } \\
\text { PONTÉRTÉK }\end{array}$ \\
\hline $\begin{array}{l}\text { OSAS-ra nem } \\
\text { gyanús }\end{array}$ & $0-168$ pont & $50 \%$ \\
\hline OSAS-ra gyanús & $169-269$ pont & $50 \%-80 \%$ \\
\hline $\begin{array}{l}\text { OSAS-ra } \\
\text { alaposan gyanús }\end{array}$ & $270-336$ pont & $80 \%-100 \%$ \\
\hline
\end{tabular}

4. táblázat. A kérdőives szürés és az ezt követö kardiorespiratórikus vizsgálatok eredményét összegző kontingencia táblázat

\begin{tabular}{|l|c|c|c|}
\hline & \multicolumn{2}{|c|}{ diagnózis } & \\
\hline $\begin{array}{l}\text { teszt } \\
\text { eredmény }\end{array}$ & $\begin{array}{c}\text { súlyos } \\
\text { OSAS }\end{array}$ & $\begin{array}{c}\text { nem } \\
\text { súlyos } \\
\text { OSAS }\end{array}$ & összesen \\
\hline $\begin{array}{l}\text { OSAS-ra nem } \\
\text { gyanús }\end{array}$ & 356 & 1802 & 2158 \\
\hline $\begin{array}{l}\text { OSAS-ra } \\
\text { gyanús }\end{array}$ & 3523 & 675 & 4198 \\
\hline összesen & 3879 & 2477 & 6356 \\
\hline
\end{tabular}

Mindezek alapján ki lehetett számolni a kérdöív szenzitivitását: 90,8\%, specificitását: $72,8 \%$, a pozitív prediktív értékét: $83,9 \%$ és a negativ prediktív értékét: 83,5\%. A kérdöív szenzitivitásának és specificitásának kapcsolata grafikusan lett ábrázolva. A kérdőívvel szembeni döntési kritériumot a ROCgörbe alapján célszerű meghozni. Jelen esetben a görbe az ábra bal felső sarkába koncentrálódott, amely a kérdőív magas szenzitivitásának és elfogadható specificitásának a tükröződése (1. ábra).

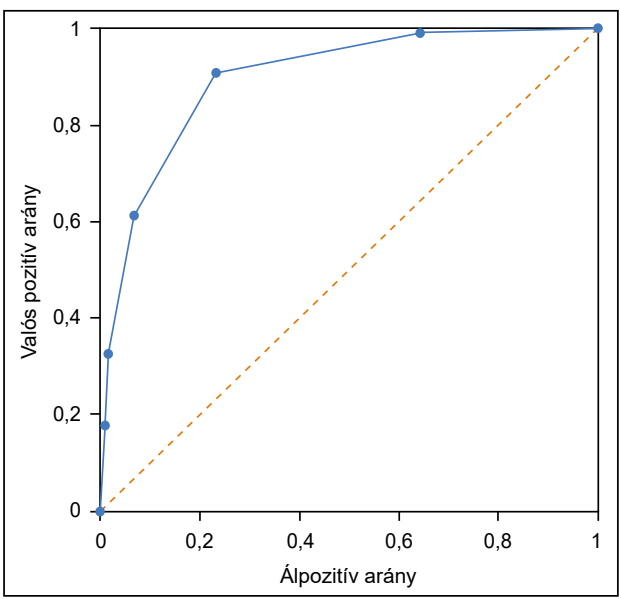

1. ábra. A kérdőív szenzitivitásának és specificitásának kapcsolatát grafikusan jellemzö ROC-görbe (Receiver Operating Charactristic)

A résztvevő családorvosok és rendelőintézeti szakorvosok számára öt alkalommal tartottunk továbbképző előadásokat, melynek témái az OSAS klinikuma, patomechanizmusa, differenciáldiagnosztikája, terápiás lehetőségei és esélyei, a korai szürés jelentősége, az alapszürés elméleti és technikai problémáinak elhárítása voltak. A továbbképző előadások során 5 olyan javaslat volt, ami az alapkérdőív szerkezetében később hasznos változtatást eredményezett. 
A tapasztalatcserék elsősorban a szürések során felmerült technikai problémák elhárítását célozták. A betegek tájékoztatására rövid brosúrát dolgoztunk ki, amit a háziorvosok a kérdöívek mellékleteként kaptak meg.

Az életmódklubokban négy felvilágosító előadást tartottunk, ahol a veszélyeztetett populáció tagjai, illetve közeli hozzátartozóik vettek részt. Ennek eredményeképpen jelentős számú középkorú férfi beteget kaptunk, akiket feleségük beszélt rá a szürésre és azt követő vizsgálatokra.

A résztvevő családorvosok továbbképzését szolgálták azok az alkalmak is, amikor megismerkedhettek az alváslaboratórium müszereivel, müködésével és a betegnyilvántartással. A gyakorlati munka és továbbképzés eredményeként a kérdőíveken megjelentek a családorvosok „előzetes véleményei”, amelyek mindinkább igazolódtak is. A gyakorlati munka eredménye volt az is, hogy az év utolsó negyedében a HM rendelökben kihelyezetten müködö elöszürésre (pulzoximéter) mind nagyobb igény mutatkozott.
5. táblázat. Az obstruktív alvási apnoe epidemiológiai szürésében résztvevők foglalkozás szerinti megoszlása

\begin{tabular}{|l|c|c|}
\hline szellemi munkakör & & $22 \%$ \\
\hline fizikai munkakör & 725 & $44 \%$ \\
\hline veszélyes munkakör & 228 & $14 \%$ \\
\hline aktív & 1315 & $80 \%$ \\
\hline nyugdíjas & 321 & $20 \%$ \\
\hline
\end{tabular}

\section{Eredmények}

\section{Az alapszürés müködésével kapcsolatos eredmények}

A beteganyag életkor és nem szerinti megoszlását a 2. ábra mutatja. Az ötévenként képzett korcsoportok szerint a vizsgált személyek 30\%-a 46-50 év, 27\%-a 51-55 év, 22\%-a 56-60 év, 13\%-a 41-45 év, 8\%-a 35-40 év közötti sávból származott. Ezt az eloszlást - összehasonlítva az OSAS morbiditásának életkori mutatóival - a kitüzött cél szempontjából jónak értékelhetjük. A foglalkozás szerinti megoszlást a 5. táblázat ábrázolja. A vizsgált személyek 80\%-a volt aktív dolgozó, 20\%-a nyugdíjas. Lényegében nem mutatott számottevő különbséget a szellemi

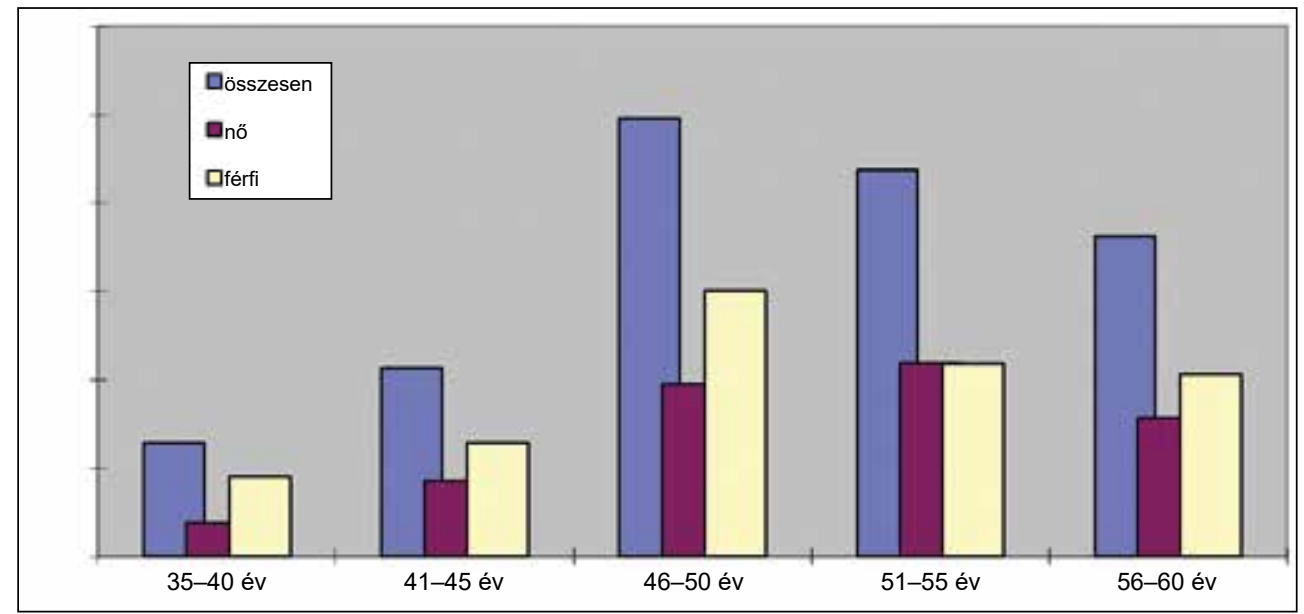

2. ábra. Az obstruktív alvási apnoe epidemiológiai szürésében résztvevők életkor szerinti megoszlása 
és fizikai dolgozók aránya. A baleseti szempontból kifejezetten veszélyes munkakörben tevékenykedők (hivatásos gépkocsivezető, darus, többmüszakos dolgozó) száma 14\% volt. Jellemző módon ezek a személyek az egyik vidéki (többmüszakos munkahelyeket nagy számban üzemeltető) körzetből jöttek. Ezen csoport aránya azt a tanulságot adja, hogy e célcsoportot az adott terület foglalkozásegészségügyi szolgálatával együtt lehet

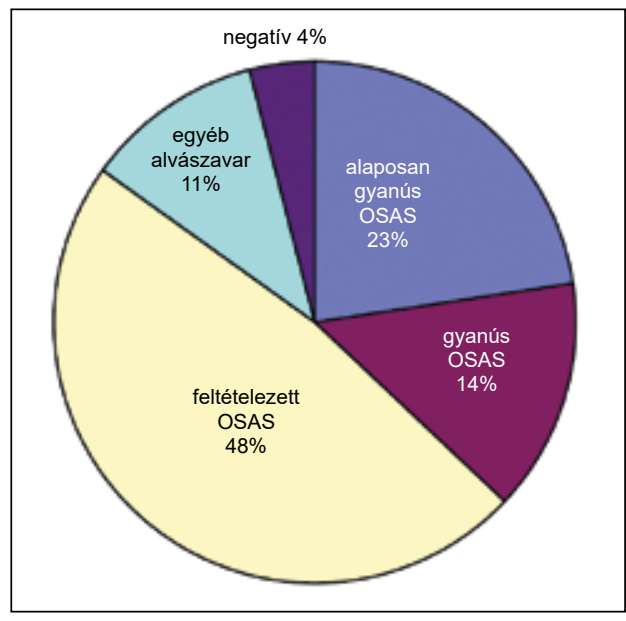

3. ábra. A kérdöívek OSAS gyanú szerinti megoszlása átvizsgálni. A kérdőívek OSAS-gyanú szerinti megoszlását a 3. ábra mutatja.

$\mathrm{Az}$ alapkérdőív kérdéscsoportjait úgy szerkesztettük meg, hogy azokból a napközbeni aluszékonyság-figyelemzavar-feledékenység mértékére, az éjszakai horkolás veszélyességére, az alvászavar súlyosságára és következményeire, a veszélyes szövődményekre (hipertónia, diabetesz, kardiáliscerebrovaszkuláris események) utaló öszszevont változókat képezhessünk az OSAS alapos gyanújának megállapításához.

A kérdőív alapján lehetőségünk volt más alvásfüggö légzészavar (UARS), egyéb alvászavar gyanújának felvetésére is. Külön figyelmet fordítottunk arra, hogy az alapos OSAS-gyanú esetén a veszélyes szövődmények jelenléte soronkívüliséget jelentsen az alváslaboratóriumi vizsgálatra történő besoroláskor.

A kérdőíves értékelés során igen magas, $23 \%$ volt az OSAS-ra alaposan gyanús, $14 \%$ a OSAS-ra gyanús, $48 \%$ a feltételezhetően OSAS-ban szenvedők aránya. 11\%ban más rendellenesség lehetősége merült fel. A megoszlásból, a gyanús személyek magas százalékából jól látszik, hogy minden szempontból „célszűrés” történt.

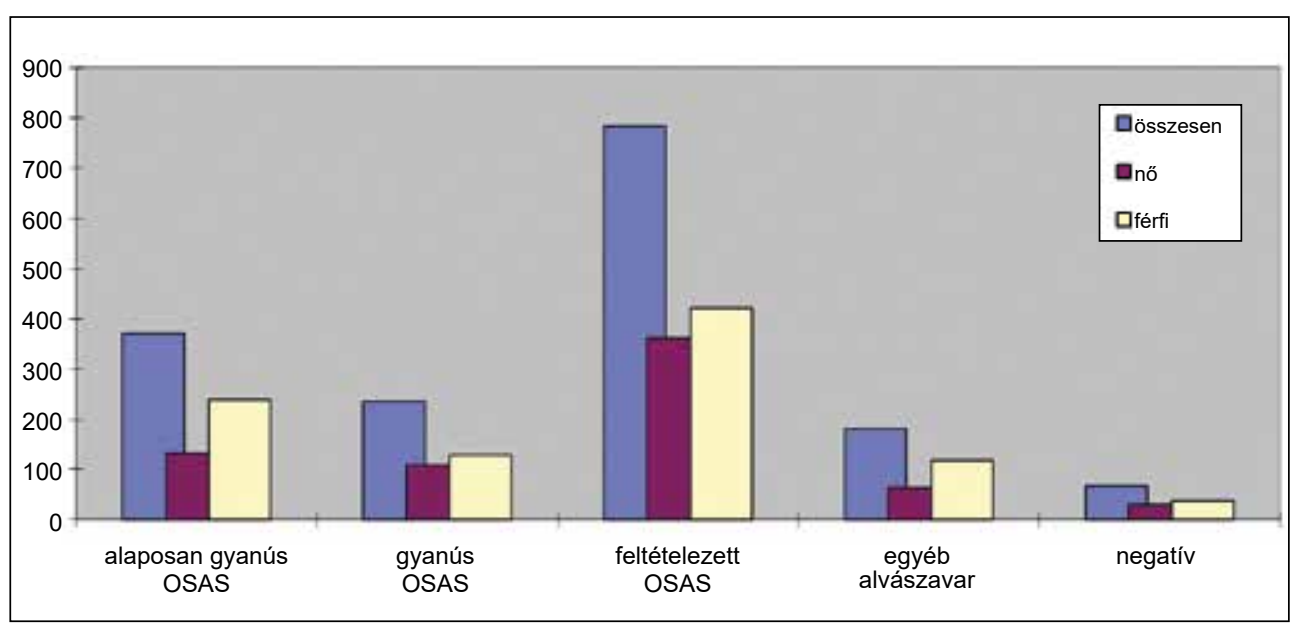

4. ábra. A kérdőivek kiértékelése után a szürésben résztvevők OSAS gyanújának és nem szerint megoszlása 


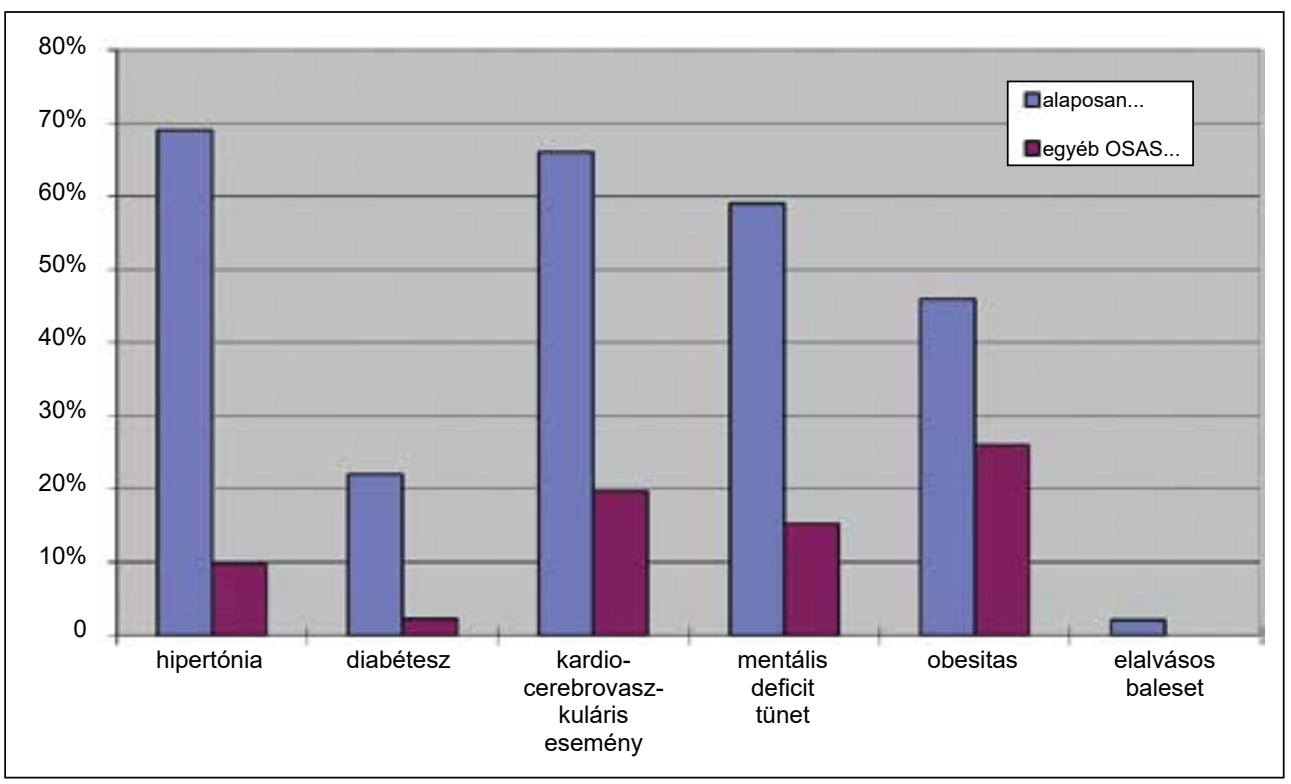

5. ábra. Az OSAS gyanús betegek között az alaptünetek, illetve szövődményes kórképek megoszlása

A kérdőívek eredményeit az OSASgyanúját és nem szerint megoszlását a 4. ábra mutatja. Az OSAS-gyanús betegek között az alaptünetek, illetve szövődményes kórképek megoszlását az 5. ábra mutatja.

Az 1019 OSAS-ra valamilyen mértékben gyanús személyek között 38\% volt hipertóniás, $8 \%$-a diabéteszes, 26\%-a túlsúlyos, $31 \%$ panaszkodott mentális deficittünetekre kórtörténetükben 35\%-ban szerepelt kardio-cerebrovaszkuláris esemény és 0,5\%-ban elalvásos közlekedési baleset. Az 1019 személyből 471 rendelkezett vezetői jogosítvánnyal. Az elalvásos balesetek előfordulása ezekre számolva már $1,1 \%$.

A 370 alapos OSAS-gyanús beteg körében az előbbi arányok már jóval magasabbak: hipertónia $74 \%$, diabétesz $14 \%$, mentális deficittünetek 57\%, kardio- illetve cerebrovaszkuláris esemény 53\%, túlsúly $46 \%$. Elalvásos baleset a 117 jogosítvánnyal rendelkező személyre számolva $4,4 \%$ volt!

\section{Az alváslaboratóriumi vizsgálatok eredményei}

$\mathrm{Az}$ alváslaboratóriumban megvizsgált betegek száma 87 volt. A behívási sorrendet a súlyossági fokozat adta, így elsősorban az alaposan gyanús személyek kerültek sorra. Néhány esetben számolnunk kellett azzal, hogy a behívott személy nem müködik együtt velünk.

A 370 alaposan gyanús személy közül csupán 9, az 1019 további enyhébb OSAS-gyanús személy közül 346 utasította vissza a poliszomnográfiás vizsgálatot. Az mindenesetre magáért beszél, hogy a panaszok és tünetek által terhelt alaposan gyanús csoport tagjai minden akadálytól függetlenül könnyen behívhatók voltak.

A kérdőíves szűrés feladata, csupán a gyanú felvetése lehet. Ennek hatékonysága természetesen jelentős mértékben függ a kérdőív megfelelő tartalmi-szerkezeti jellemzőitől, a szürőmunka szervezettsé- 
gétől, a benne résztvevők elkötelezettségétől.

A diagnózis megállapítása az alváslaboratórium diagnosztikai feladata. Ennek során tisztázni kell a kórkép jellegét, esetleges szövődményes voltát és az OSAS klinikai súlyosságát, ami a kezelés alapvető stratégiáját határozza meg.

Ezen diagnosztikus alapelvek szerint a 87 vizsgált személy közül 29 (33\%) súlyos OSAS-betegnek, 16 (18\%) közepes-, illetve enyhe OSAS-betegnek bizonyult. További 37 személy az alvásfüggő légzészavarok valamilyen egyéb formájában szenvedett. Egy alvásfüggő mozgászavart, négy eddig még nem tisztázott alvás-ébrenlét zavarban szenvedő beteget találtunk (6. és 7. ábra).

$\mathrm{Az}$ alap és előszürés során alaposan gyanús 87 beteg között $81 \%$ bizonyult alvásfüggő légzészavarosnak, 33\%-uk volt súlyos, $18 \%$-uk közepes, illetve enyhe OSAS-beteg. Az eredmény azt bizonyítja, hogy a szürés hatásfoka megfelelő volt. Nemzetközi viszonylatban az egyszerü kérdőíves alapszürés hatásfo-

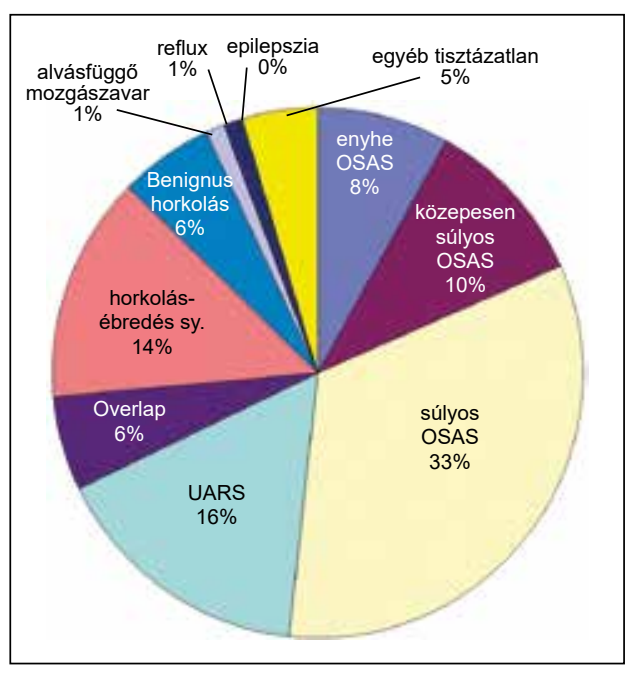

6. ábra. Az alváslaboratóriumban megvizsgált személyek megoszlása az egyes kórképek szerint ka $20-30 \%$. Ez egyértelműen a lépcsőzetes diagnosztika, illetve a párhuzamosan folytatott továbbképző és felvilágosító munka eredménye volt.

\section{A pulzoximetriás előszürés jelentősége}

$\mathrm{Az}$ előszűrés részeként a betegek egy csoportjában pulzoximetriás előszürést iktattunk be. Ezzel két célunk volt:

1. Ellenőrizni az irodalmi adatok által leírt gyenge mérési hatásfokot.

2. Csökkenteni és ökonomizálni a poliszomnográfiás vizsgálatokra nehezedő terhelést.

42 alaposan gyanús személy esetében végeztünk elözetes pulzoximetriát. Ezek közül a PSG vizsgálatok szerint 26 súlyos, 16 enyhe-közepes OSAS-nak bizonyult. A súlyos csoport mindegyik betegénél jellemző volt az előzetesen felvett $\mathrm{O}_{2}$ szaturációs profil és pulzushisztogram, 19 esetben még a végső beosztással is egyezett az elözetes vélemény. Az enyhe- közepes csoportban csak 9 betegnél találtak jellemző éjszakai $\mathrm{O}_{2}$ szaturációs profilt.

Bár ezek az eredmények még további megerösítésre szorulnak, az mégis már levonható belölük, hogy megfelelően szervezett szürőhálózat és komplex szűrés esetén a pulzoximetriás elöszűrés hatásfoka lényegesen javitható.

\section{Terápiás eredmények}

Az OSAS esetében különösen áll, hogy minden beteg a kórkép egyéni kombinációjával rendelkezik. Ennek gondos feltérképezése, a kórkép egyéni profiljának megrajzolása alapvetően fontos az egyénre szabott, várhatóan sikeres, hosszabb távon is eredményes terápiának. 


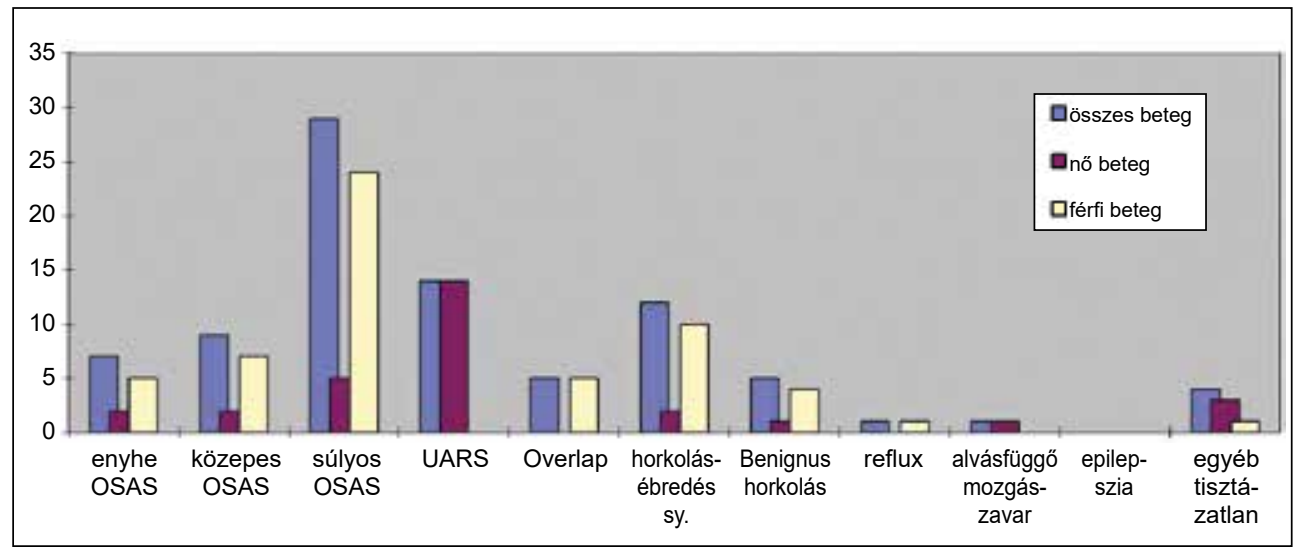

7. ábra. Az alváslaboratóriumban megvizsgált személyek egyes kórképek és nem szerint megoszlása

Az OSAS egyénre szabott terápiás stratégiáját az alábbi tényezők határozzák meg:

1. Tisztázni kell, van-e a kórkép hátterében jól azonosítható anatómiai ok?

2. Van-e a háttérben az OSAS okaként azonosítható elsődleges kórkép?

(hyper-és hypothyreosis, akromegália stb.)

3. Az adott kórkép klinikai súlyosságát a következő paraméterekből szükséges megállapítani:

- a jellemző klinikai tünetek (nappali alváskésztetés, reggeli fejfájás és tompaság, felsőlégúti gyulladások, reggeli szájszárazság, hipertónia, személyiségváltozás, memória problémák),

- az adott kórkép előrehaladott stádiumát jelző veszélyes szövődmények (feltünő napközbeni álmosság, cor pulmonale, szívritmuszavar, éber állapotban is észlelhető hypoxia, illetve hypercapnia, polyglobulia, a kórelőzményi adatokban az OSAS tüneteinek progressziója, stroke, myocardialis infarktus),

- a poliszomnográfia és az elektrofiziológiai vizsgálatok eredményei (apnoe index, minimális $\mathrm{O}_{2}$ szaturáció értékek, alváslatencia értékek) alapján.

$\mathrm{Az}$ adott beteg esetében mindezek, illetve az egyes kezelési módok várható előnyős, illetve hátrányos hatásainak számbavétele alapján születhet meg a terápiás stratégia.

$\mathrm{Az}$ alváslaboratóriumi vizsgálatok után a 8 „overlap" szindrómás beteget leszámítva 79 OSAS-beteg várt a kezelési terv kialakítására. A 79 betegből 35 fő súlyos, 30 fő közepes, 14 fö enyhe OSAS-beteg volt. A kezelt OSASbetegek terápiás folyamatát a szürés befejezésekor a 8. ábra mutatja. Gyógyultnak akkor tekintettük a beteget, ha mind klinikailag, mind PSG szerint teljesen tünetmentessé vált. Javulást akkor állapítottunk meg, ha a beteg a súlyossági fokozatban legalább egy kategóriával lejjebb került.

A gyógyulás kritériumait a PSG eredménye, a klinikai kép (státus, mérőszámok, szubjektív beszámoló, Epworthkérdőív, háziorvosi beszámoló, vérnyomás rendeződés), illetve a szubjektív beszámoló alapján ítéltük meg. A terápiás 
eszközöket az alábbi nemzetközileg elfogadott elvek alapján vettük igénybe:

Az enyhe OSAS-betegek esetén elsősorban életmód és gyógyszeres terápiát alkalmaztunk. A középsúlyos OSASbetegek esetén e két módszer mellett, szükség szerint a mechanikus kezelés mindkét formáját igénybe vettük. A súlyos OSAS-betegek kezelésének tengelyében a CPAP terápia állt.

Az életmód-terápiák között az alváshigiénés ismereteket, célzott testsúlycsökkentési tréninget, komplex - pszichés vezetést is magába foglaló - tréninget, gyógyszeres megszorításokat alkalmaztunk.

A gyógyszeres terápia során szerotonin reuptake gátlókat, fluoxetin, cilazaprilt, theophyllint vettünk igénybe.

A mechanikus kezelés eszköze a CPAP készülék volt. BIPAP készüléket csak a beállítás során használtunk. A súlyos OSAS-betegek közül 35 esetben elvégeztük az alváslaboratóriumi beállítást, a titrálást. Ezeket az egyéneket a gondozás szakmai szabályai szerint jelenleg is ellenőrizzük.

Napjainkban az enyhébb esetekben alkalmazott szájbetét típusokkal a tapasztaltszerzés és alváslaboratóriumi ellenőrzés stádiumában vagyunk, ezek eredményéről még korainak tartunk nyilatkozni.
Műtéti megoldás két alkalommal történt, mindkét esetben retrosternális struma eltávolítására került sor.

Minden egyes beteg esetében - lehetőség szerint - a komplex kezelésre törekedtünk. Ez legalább két terápiás lehetőség együttes alkalmazását jelentette.

Az obstruktív alvási apnoe epidemiológiai szürése során a morbiditási adatok alapján megállapitott célpopulációban (1500 fó) 81 esetben igazolódott az alvásfüggö légzészavar valamilyen súlyosságú formája. Az OSAS prevalenciája 5,4\%-osnak bizonyult.

\section{Diszkusszió}

Az izraeli Lavie (6. táblázat) keresztmetszeti tanulmányának becslése szerint a szindróma prevalenciája a férfi ipari dolgozók között legalább 1\% [15]. Az olaszországi Bolognában végzett epidemiológiai vizsgálatban a szerzők a poliszomnográfiai eredmények alapján ebben a populációban a minimális prevalenciát $2,7 \%$-ra becsülték. Ezek az adatok nagyobbak, mint a skandináv vizsgálatokban $[16,17]$. A legmagasabb érték (8,5\%) Bearpark és munkatársainak ausztrál tanulmányából származik [18].

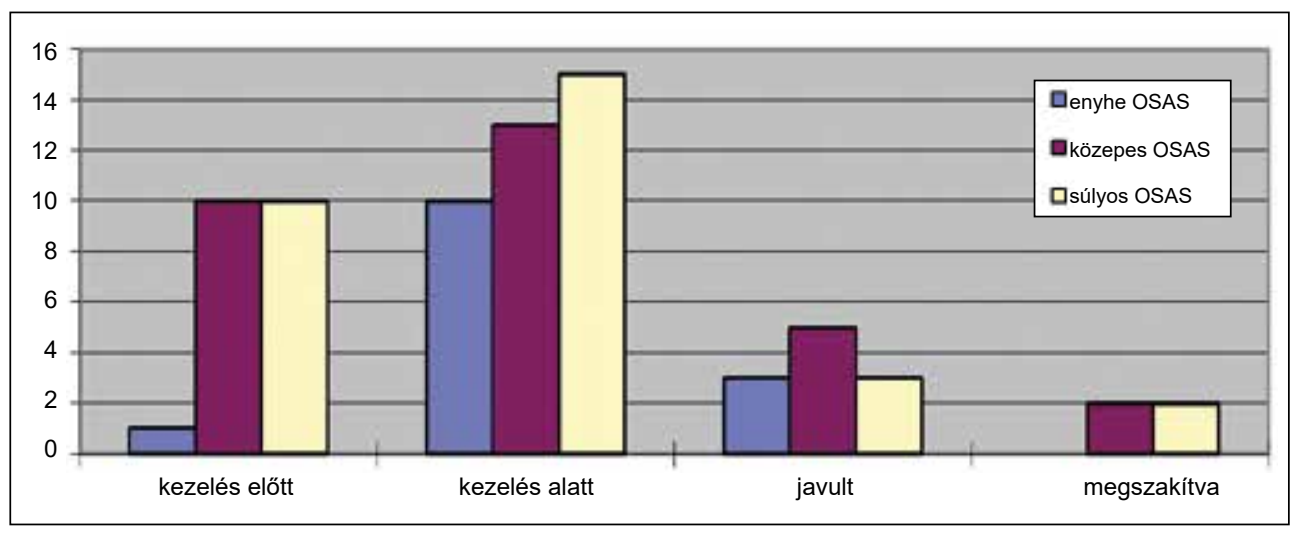

8. ábra. A különbözö súlyosságú OSAS betegeink a terápia folyamatában 
Bár számos nagyszabású epidemiológiai vizsgálat becsülte már meg az OSA elterjedtségét, az alvási apnoe diagnosztizálásához használt módszerek és az AHI küszöbértékének eltérései, valamint a változatos populációs mintavételi sémák változó eredményeket hoztak. Az első és legszélesebb körben idézett tanulmány, a Wisconsin Sleep Cohort tanulmány a közelmúltban beszámolt arról, hogy a 30-70 éves résztvevők között a közepes vagy súlyos OSA (azaz AHI $\geq 15$ esemény / óra) előfordulása $10 \%$ volt (95\% CI, $8-11 \%)$ (3). A szerzők arra a következtetésre jutottak, hogy az életkortól és a nemtől függően ez az OSA prevalenciájának 14-55\%-os növekedését jelentette ugyanezen kohorsz 20 évvel korábban mért értékeihez képest $[19,20]$.

A mérsékelt vagy súlyos OSA sokkal gyakoribb előfordulásáról (férfiak $50 \%$-a, nők 23\%-a) számoltak be később egy svájci vizsgálatban [21]. Míg ugyanez ausztrál férfiak esetében 26\% [22]. Úgy tünik, hogy e növekedés a tanulmányok kiválasztási és pontozási módszereinek nagyobb érzékenységével volt magyarázható $[21,23]$.

A legkorábbi obszervációs tanulmányok egy része összefüggést igazolt az alvási apnoe (illetve a helyettesítőjeként használt horkolás) és a kardiovaszkuláris betegségek között [24]. Ezt azóta nagyszabású epidemiológiai vizsgálatok erősítették meg. Az OSA (poliszomnográfiás alvásvizsgálattal mért) és a kardiovaszkuláris betegségek közötti összefüggés a rizikótényezők korrekciója után is fennmaradt igen magas kockázattal $[25,26$, 27, 28]. Köztudott, hogy a metabolikus szindróma, amelyet az elhízás, a magas vérnyomás, az inzulinrezisztencia és a hiperlipidémia együttes jelenléte határoz meg, növeli a szív- és érrendszeri be- tegségek kockázatát. Az OSA és a metabolikus szindróma kapcsolatát vizsgáló szisztematikus áttekintés szerint az OSAban szenvedő betegeknél a metabolikus szindróma esélyaránya $(\mathrm{OR}) 2,87$, illetve 2,56 volt [29].

Azt azonban, hogy az OSA egyszerüen „szemlélő"-e a metabolikus szindrómában, vagy a metabolikus teher növekedését ösztönzi, még nem tisztázott megfelelően. A kutatások szerint az OSA okozta hipoxiának jelentős szerepe van a szív- és érrendszeri betegségek kialakulásában. Egy 2872 idősebb férfibetegből álló kohorsz vizsgálatban a súlyos éjszakai hipoxaemiában szenvedő betegeknél, amely meghatározása szerint az éjszakai több, mint 10\%-át töltötték 9\%-os oxygén szaturáció alatt, 1,8-szoros volt a stroke kockázata az éjszakai hipoxiával nem rendelkezőkhöz képest [30]. Egy másik prospektív vizsgálat, amelyben 112 szívinfarktusban szenvedő betegnél végeztek poliszomnográfiás vizsgálatot, megállapította, hogy az éjszakai hipoxaemia, amelyet $85 \%$ alatti mélységig tartó deszaturációként definiálnak, független kockázati tényező a súlyos, nemkívánatos kardiális események szempontjából [31].

Az OSA-ban megfigyelhető hipoxia jelentős mértékben fokozódik REM fázisban, a REM fázis során kialakuló atónia miatt. A REM alvás a teljes alvási idő körülbelül 15-25\%-át teszi ki egészséges egyéneknél, és fóleg az éjszaka második részében fordul elö. Az alvás ezen fontos szakaszát az izomtónus csökkenése, a gyors szemmozgások, a légzési mintázat megváltozása és az álomtevékenység jellemzi. A felső légutak fokozódó kollapszibilitása miatt az obstruktív események a REM-alvásban általában hosszabbak és nagyobb oxigén-deszaturációval társulnak, mint 
a nem-REM-alvásnál tapasztaltak. Az izolált REM OSA-t az OSA vizsgálatára utalt betegek 10-37\%-ánál látják [32].

A katonai szolgálat (a békefenntartó missziókban is nagy jelentőségü őrzésvédelem és szállítás), a szolgálat megfelelő szintü ellátásához olyan neuropszichológiai funkciókat igényel a szolgálatot tevővel szemben, mint az állandó éberség, a tartós figyelem és koncentráció, továbbá a gyors, felelősségteljes döntéshozatal kényszere. A szolgálat ellátásához azonban gyakran nehéz külső körülmények társulnak, mint például a monotonitás, a zord időjárási tényezők, vagy a váltott müszak, amelyek komoly megterhelést jelentenek a szolgálatot tevő számára. A katonai szolgálat során a változatos müszak beosztás mellett várunk el a szolgálatot tevőtől gyakran különleges pszichikai és fizikális teljesítményt.

A többműszakos beosztás azonban megtöri a katona cirkadián ritmusát, anyagcsere és hormonális változásokat idéz elő, és komoly befolyást gyakorol viselkedésére és az adott teljesítmény során mélyen alul maradhat önmagához képest is. Nem mindenki adaptábilis az ilyen feltételekhez, különösen hátrányban vannak az elsődleges alvászavarban szenvedők. Éppen ezért különös jelentőséggel bír a többmüszakos munkakör betöltése a primer alvásbetegek körében. A súlyos obstruktív alvási apnoeban szenvedők nappali alváskésztetése kóros mértékben fokozódik és a többmüszakos munka körülmények között figyelmük, koncentráló képességük, vigilanciájuk, munka és kognitív teljesítményük társaikhoz képest jelentős mértékben hanyatlik.

$\mathrm{Az}$ alvászavarok és alvásbetegségek terén összegyült sok tapasztalat természetesen csak akkor értékesíthető a kato- nai és katasztrófa orvostan területén, ha gyakorlattá válik. Egyik fó célunk volt, hogy a MH Egészségügyi Központ egyik fő szakmai és tudományos témájává tegyük az ide tartozó kórképek diagnosztizálását, kezelését, szürésének megszervezését. Ennek érdekében összeállítottuk az inszomnia-hiperszomnia szindrómák, illetve a paraszomniák kivizsgálásának és kezelésének protokolljait, amelyek meghatározzák az alapellátásban (csapatorvosi, háziorvosi rendelők), valamint kórházunk szakambulanciáján és egyes esetekben az osztályon szükséges teendőket. A katonai egészségügyben működő alvásdiagnosztikai laboratóriumnak feladata kiszürni a speciális több müszakos körülmények közötti teljesítő katonákból a disszomniában szenvedőket.

\section{Irodalom}

[1] Bixler, E.O., Vgontzas, A.N., Lin H.M., et al.: Prevalence of sleep-disordered breathing in women: effects of gender. Am. J. Respir. Crit. Care Med., 2001, 163(3 Pt 1): 608.

[2] Jennum, P., Riha, R.L.: Epidemiology of sleep apnoea/hypopnoea syndrome and sleepdisordered breathing. Eur. Respir. J., 2009, 33(4): 907.

[3] Young, T., Palta, M., Dempsey, J., et al.: Burden of sleep apnea: rationale, design, and major findings of the Wisconsin. Sleep Cohort study. WMJ, 2009, 108(5): 246.

[4] Benjafield, A.V., Ayas, N.T., Eastwood, P.R., et al.: Estimation of the global prevalence and burden of obstructive sleep apnoea: a literature-based analysis. Lancet Respir. Med., 2019, 7(8): 687.

[5] Markku Partinen and Tiina Telakivi: Epidemiology of Obstructive Sleep Apnea Syndrome. Sleep. American Sleep Disorders Association and Sleep Research Society. 1992, 15:S1-84 (c)

[6] Won Lee, Swamy Nagubadi, Meir H. Kryger, Babak Mokhlesi: Epidemiology of Obstructive Sleep Apnea: a Population-based Perspective Expert. Rev. Respir. Med., 2008, 2(3): 349364. DOI:10.1586/17476348.2.3.349. 
[7] Paroma Sarkar, Sutapa Mukherjee, Ching Li Chai-Coetzer, R. Doug McEvoy: The epidemiology of obstructive sleep apnoea and cardiovascular disease. J. Thorac. Dis., 2018, 10(Suppl 34): S4189-S4200.

[8] Franklin, K.A., Lindberg, Eva: Obstructive sleep apnea is a common disorder in the population. Review on the epidemiology of sleep apnea. J. Thorac. Dis., 2015, 7(8): 13111322.

[9] Garvey, J. F., Pengo, M.F., Drakatos, P., Kent, B.D.: Epidemiological aspects of obstructive sleep apnea. J. Thorac. Dis. 2015, 7(5): 920 929.

[10] Young, T., Peppard, P.E., Gottlieb, D.J.: Epidemiology of Obstructive Sleep Apnea A Population Health Perspective. Am. J. Respir. Crit. Care Med., 2002, 165: 1217-1239. DOI: 10.1164/rccm.2109080

[11] Young T, Palta M, Dempsey J, et al.: Burden of sleep apnea: rationale, design, and major findings of the Wisconsin Sleep Cohort study. WMJ, 2009:108(5):246.

[12] Kenia Vieira da Silva, Maria Luiza Garcia Rosa, Antônio José Lagoeiro Jorge,et al.: Prevalence of Risk for Obstructive Sleep Apnea Syndrome and Association With Risk Factors in Primary Care. Arq. Bras. Cardiol., 2016, 106(6): 474-480. DOI: 10.5935/ abc. 20160061

[13] Torzsa P., Kalabay L., Ádám Ágnes et al.: Az obstruktiv alvasi apnoe klinikai jelentősége, a családorvos szerepe a betegek kezeléseben, valamint gondozásában. 2010, 151(42): 1725-1733. DOI: 10.1556/OH.2010.28948

[14] Ádám Ágnes: OSAS - A terápiarezisztens hipertónia gyakori oka. Metabolizmus, 2018, 16(5): 304-7.

[15] Lavie, P.: Sleep apnea in industrial workers. In: Guilleminault C., Lugaresi, E. eds.: Sleep/ wake disorders: natural history, epidemiology, and long-term evolution. New York, Raven Press, 1983, 127-35.

[16] Telakivi, T., Partinen, M., Koskenvuo, M., et al.: Periodic breathing and hypoxia in snorers and controls: validation of snoring history and association with blood pressure and obesity. Acta Neurol. Scand., 1987, 76: 69-75.

[17] Gislason, T., Almqvist, M., Eriksson, G., et al.: Prevalence of sleep apnea syndrome among Swedish men - an epidemiological study. J. Clin. Epidemiol., 1988, 41: 571-6.
[18] Bearpark, H., Elliott, L., Cullen, S., et al.: Home monitoring demonstrates high prevalence of sleep disordered breathing in men in the Busselton population. Sleep Res., 1991, 20A:411.

[19] Punjabi, N.M.: The Epidemiology of Adult Obstructive Sleep Apnea. Proceedings of the American Thoracic Society, 2008, 5:136-43.

[20] Young, T., Palta, M., Dempsey, J., et al.: The occurrence of sleep-disordered breathing among middle-aged adults. N. Engl. J. Med., 1993, 328:1230-5.

[21] Heinzer, R., Vat, S., Marques-Vidal, et al.: Prevalence of sleep-disordered breathing in the general population. Lancet Respir. Med., 2015, 3: 310-8.

[22] Adams, R., Appleton, S., Taylor, A., et al.: Are the ICSD-3 criteria for sleep apnoea syndrome too inclusive? Lancet Respir. Med., 2016 4:e 19-20.

[23] Jennum, P., Riha, R.L.: Epidemiology of sleep apnoea/hypopnoea syndrome and sleepdisordered breathing. Eur. Respir. J., 2009, 33: 907-14.

[24] Koskenvuo, M., Partinen, M., Sarna, S., et al.: Snoring as a risk factor for hypertension and angina pectoris. Lancet, 1985, 1:893-6.

[25] Peppard, P.E., Young, T., Palta, M., et al.: Prospective study of the association between sleep-disordered breathing and hypertension. N. Engl. J. Med., 2000, 342:1378-84.

[26] Punjabi, N.M., Caffo, B.S., Goodwin, J.L., et al.: Sleep- Disordered Breathing and Mortality: A Prospective Cohort Study. PLoS Med. 2009, 6:e1000132.

[27] Gottlieb, D.J., Yenokyan, G., Newman, A.B., et al.: Prospective study of obstructive sleep apnea and incident coronary heart disease and heart failure: the sleep heart health study. Circulation, 2010, 122: 352-60.

[28] McNicholas, W.T., Bonsignore, M.R.: Sleep apnoea as an independent risk factor for cardiovascular disease: current evidence, basic mechanisms and research priorities. Eur. Respir. J., 2007, 29:156-78.

[29] Xu S, Wan Y, Xu M, et al. The association between obstructive sleep apnea and metabolic syndrome: a systematic review and metaanalysis. BMC Pulm. Med., 2015, 15:105.

[30] Stone, K.L., Blackwell, T.L., Ancoli-Israel S., et al.: Sleep Disordered Breathing and Risk of Stroke in Older Community-Dwelling Men. Sleep, 2016, 39:531-40. 
[31] Xie J., Sert Kuniyoshi F.H., Covassin, N., et al.: Nocturnal Hypoxemia Due to Obstructive Sleep Apnea I is an Independent Predictor of Poor Prognosis After Myocardial Infarction. J. Am. Heart Assoc., 2016, 5.

[32] Kass, J.E., Akers, S.M., Bartter, T.C., et al.: Rapid-eye-movement-specific sleep-disordered breathing: a possible cause of excessive daytime sleepiness. Am. J. Respir. Crit. Care Med., 1996, 154:167-9.

\section{Col. Z. Szakács MDMC, PhD}

\section{Epidemiological screening for obstructive sleep apnea in a target population}

Obstructive sleep apnea (OSA) is probably the most common sleep-related respiratory disorder. According to the latest data from the United States and Europe, $14-49 \%$ of middle-aged men have clinically significant OSA. The close relationship between OSA and obesity means that its prevalence is significantly increased in the context of the global obesity epidemic. At the individual level, OSA leads to a significant decrease in quality of life and functional capacity with a significantly increased risk of cardiovascular disease and death. Emerging data also suggest that the presence and severity of OSA and associated nocturnal hypoxemia are associated with an increased risk of diabetes and cancer. At the societal level, OSA not only leads to declining economic productivity, but is a major manageable risk factor for hypertension, coronary heart disease, and stroke. This article deals with the prevalence of OSA and co-morbidity in Hungary from an epidemiological point of view.

Key-words: sleep apnea, cardiovascular, obesity

Dr. Szakács Zoltán o. ezds., $P h D$ 1134 Budapest, Róbert Károly krt. 44. 